IRA-International Journal of Management \&

Social Sciences

ISSN 2455-2267; Vol.16, Issue 04 (Oct.-Dec. 2020)

Pg. no. 139-146.

Institute of Research Advances

http://research-advances.org/index.php/RAJMSS

\title{
Does the Export of Agricultural Products Lead to Economic Growth in Cameroon?
}

\author{
Younchawou NGOUWOUO ${ }^{1}$, Zenabou TOURERE ${ }^{2}$, Samuel Honoré NTAVOUA ${ }^{3 \#}$ \\ ${ }^{1}$ University of Dschang, Cameroon. \\ ${ }^{2}$ University of Douala, Cameroon. \\ ${ }^{3}$ University of Yaoundé II, Cameroon.
}

\# corresponding author

Type of Work: Peer Reviewed.

DOl: http://dx.doi.org/10.21013/jmss.v16.n4.p2

How to cite this paper:

NGOUWOUO, Y., TOURERE, Z., NTAVOUA, S. (2020). Does the Export of Agricultural Products Lead to Economic Growth in Cameroon? IRA-International Journal of Management \& Social Sciences (ISSN 24552267), 16(4), 139-146. doi:http://dx.doi.org/10.21013/jmss.v16.n4.p2

(C) Institute of Research Advances.

(c) EY-NC This work is licensed under a Creative Commons Attribution-NonCommercial 4.0 International License subject to a proper citation to the publication source of the work.

Disclaimer: The scholarly papers as reviewed and published by the Institute of Research Advances (IRA) are the views and opinions of their respective authors and are not the views or opinions of the IRA. The IRA disclaims of any harm or loss caused due to the published content to any party.

Institute of Research Advances is an institutional publisher member of Publishers International Linking Association Inc. (PILA-CrossRef), USA. The institute is an institutional signatory to the Budapest Open Access Initiative, Hungary advocating the open-access of scientific and scholarly knowledge. The Institute is a registered content provider under Open Access Initiative Protocol for Metadata Harvesting (OAI-PMH).

The journal is indexed \& included in WorldCat Discovery Service (USA), CrossRef Metadata Search (USA), WorldCat (USA), OCLC (USA), Open J-Gate (India), EZB (Germany) Scilit (Switzerland), Airiti (China), Bielefeld Academic Search Engine (BASE) of Bielefeld University, Germany, PKP Index of Simon Fraser University, Canada. 


\begin{abstract}
The purpose of this article is to analyze the impact of agricultural exports such as coffee, cotton and cocoa on economic growth in Cameroon. The main results obtained by the Generalized Moments Method show that the impact of cocoa and coffee exports is negative and that of cotton on economic growth is positive. The export of cocoa, the exchange rate and the stability of agricultural exports are respectively significant. To this end, farmers should be encouraged to form more cooperatives in order to have easy access to finance which permit to increase their production, the government should fund research activities to improve the quality of agricultural products sold abroad in order to be more competitive and finally to promote the strategy of diversification of export products.
\end{abstract}

JEL Codes: O13, O47.

Keywords: Agricultural Exports, Economic Growth, GMM.

\title{
I. Introduction
}

Economic diversification through export is seen as one of the concerns of developing countries. The Economic and Monetary Community of Central Africa (CEMAC) cannot stand aside from this concern, because in the aftermath of the independence of the CEMAC countries, the promotion of agriculture through the export of agricultural products was at the forefront of economic opening policies.

In the context of Cameroon, the recognition of the positive link between export and economic growth has favored the identification of policies aimed at promoting this sector. Being regarded as the locomotive in the CEMAC zone, Cameroon put on the morrow of its independence the five-year plans which enabled it to improve the living conditions of the peasants. But the oil shock of the 1970s and the fact that the appreciation of the dollar from 1985 onwards was not taken into account led to a drop in agricultural production (cotton, cocoa, coffee, etc.). Following this crisis, the Structural Adjustment plan was put in place, which favored the devaluation of the FCFA in 1994, with the main objective of reviving agricultural production and exports. Indeed, in the aftermath of this devaluation, the recovery in economic growth was influenced by the revival of agricultural production. It was after the completion point of the Heavily Indebted Poor Countries Initiative (HIPCI) in 2006 that the concern for economic diversification began, so as not to be the victim of any oil shock, especially since, the country supports the pump price of oil.

The attention paid to the agricultural sector shows that it contributes $22.9 \%$ to the GDP and employs $62 \%$ of the active population, represents $23 \%$ of agricultural exports (MINADER, 2015). The main export products from Cameroon are coffee, cotton, cocoa, bananas, rubber, etc. Between 2002 and 2008, cocoa production (beans and derivatives) increased from 170 thousand tonnes to 190 miles and exports from 153.2 miles to 165.2 thousand tonnes (MINADER, 2010). National coffee production between 2012 and 2013 was 16,142 tonnes less than 58\% of the previous year. This underperformance led the government to set up in 2014 a recovery plan for coffee and cocoa. Cotton production stood at 240 thousand tonnes in 2013/2014 compared to 210 thousand tonnes in 2012/2013 (MINADER, 2015). The overall perennial crop sectors experienced a slight improvement in their production despite some reasons that explain stagnation. it is worth highlighting, among other things, the instability and the strong downward trend in prices on export markets, the weak negotiating power of planters vis-à-vis buyers and the new opportunities offered by the national market for food products.

The main objective of this article is to examine the contribution of agricultural exports to economic growth in Cameroon. This is in line with the objectives of the Cameroon emergency plan by 2035. Thus, the importance of agriculture through the exportation of cocoa, coffee, cotton will have an influence on economic growth but to what extend? The studies shall be presented as follows; literature review, methodology, results and discussions, and conclusion.

\section{Literature review \\ II.1 Theoretical review}

The pioneers of development economics: Rosenstein (1943), Lewis (1954) and Hirschman (1958) consider agriculture as "a carrier of water for industry". They believe that the role of agriculture in development is to supply the economic industry. More precisely, according to this traditional approach, agriculture would contribute to 
development through the market by providing labor for urbanized industrial employment; producing food for a growing population with increasing incomes; creating savings that will finance investments in industry; allowing the widening of the market for industrial products; generating export earnings to finance the purchase of imported capital goods, and producing raw materials for agro-industries. In this approach, agriculture ultimately appears as a source of resource transfer to industry and urban centers, a kind of "cash cow".

In contrast, modern analysis with authors such as Kuznets (1968), Kalechi (1971), Mellor (1976), Adelman (1984), De Janvry (1984) and Vogel (1994), consider the agricultural sector as an accelerator of development economics. Indeed, these authors show that agriculture plays a broader role in development than the simple role of transferring income to industry. Rostow (1963) defined the stages of the development of a country, namely: the preconditions for start-up, the start, the march towards maturity, the era of mass consumption. The author highlights the revival of the agricultural sector in the first two phases to be able to reach the era of mass consumption. So according to him, the promotion of the agricultural sector, source of foreign exchange from exports is not to be abandoned.

Mercantilists such as William Petty (1923-1687), Richard Cantillon (1680-1734) and David Hume (1711-1776), advocate state intervention in an economy to boost supply (and especially agricultural production ) and the promotion of foreign trade in order to be able to gather precious metals from exports (agricultural export which allows us to accumulate foreign exchange). The first liberals, like the physiocrats, gave importance to the land (François Quesnay, 1694-1774). According to the latter, only agriculture can generate a net product for consumption which measures the productive capacity of the land. From the input-output matrix, agriculture is considered to be the only activity to have a production above its costs, hence the concern for most developing countries of reviving this sector which is favorable for industrialization.

Referring to the theoretical foundations of international trade, the international division of labor advocates the distribution of different specializations between the countries of the world. It is based on the exchange of raw materials and basic products (cocoa, coffee, cotton, for example) from developing countries (developing countries) for manufactured products exported by industrialized countries. Therefore, developing countries must specialize in the production of raw materials (development of the agricultural sector) because of the favorable conditions (varieties of natural resources, climate, etc.) which are offered to them to boost their economic growth. In the same vein, Adam Smith, seeking to defend the idea of free trade at the end of the 18th century shows that a country should not hesitate to buy from abroad (import) what foreign producers can produce cheaper than domestic producers. The country that sells a certain product cheaper than all the other countries thus has an absolute advantage for this product. He, therefore, concludes that it would be important for countries to specialize in the production of the goods for which they have this absolute advantage and to buy all other goods. David Ricardo intervenes for his part in the 20th century and demonstrated that, even if one country was less well placed than the others for goods, it had to specialize in the production for which its disadvantage was the least: This is the theory of comparative advantage.

\section{II.2. Empirical review}

There is significant literature on the role of exports in economic growth. Over the past two decades, much empirical research has been conducted to determine the effects of exports on economic growth, or the growth hypothesis driven by exports. These studies used time series or cross-sectional data with different conclusions. Previous studies by Balassa (1978), Heller and Porter (1978), Kormendi and Mequire (1985) analyzed the relationship between economic growth and exports using the technical coefficient of simple correlation. They conclude that there is a strong correlation between economic growth and exports.

The second group of authors such as Voivades (1973), Feder (1983), Ram (1987), and Ukpolo (1994) has used technical regression to study the relationship between export growth and economic growth, considering they neoclassical growth equation. They found a positive and highly significant value for the growth coefficient of the export variable.

The third group of researchers such as Jung and Marshall (1985), Darrat (1987), Chow (1987) has examined the causal relationship between export growth and economic growth using the granger causality test. Their studies conclude that there is obviously a causal relationship between these two variables. 
Muhammad (2012), will join Heller and Porter (1978), Kormendi and Mequire (1985) in the case of Pakistan. The main objective was to explore and quantify the contribution of agricultural exports to economic growth. He estimated the relationship between GDP and agricultural and non-agricultural exports, using Johansen's cointegration techniques from 1972 to 2008. This study shows that agricultural export has a negative sign and significantly affects economic growth, while the elasticity of agricultural exports is 0.58 . In addition, there is a twoway causality between agricultural exports and real GDP. He suggests encouraging non-agricultural exports to Pakistan.

Empirical analysis of agricultural exports and economic growth in Nigeria has been carried out by various authors. Oluwaseun et al. (2013) studied the existence of long-term relationships between agricultural exports and economic growth using time series from 1980 to 2010. The study used unit root tests and Johansen's maximum likelihood test. The long-term equilibrium relationship exists between agricultural exports and economic growth, and the relationship is elastic in nature, which means that a unit increase in agricultural exports would lead to a more than proportional increase in real gross domestic product in Nigeria . Ekiran et al. (2014) examined the relationship between agricultural exports and economic growth using a multivariate co-integration analysis by Johansen for the period from 1980 to 2012 and found that agricultural exports are long-term determinants of economic expansion. They conclude that strategies to improve agricultural exports in the process of economic growth in this country should be strengthened.

In the context of Cameroon, Noula et al. (2014) studied the impact of agricultural exports on economic growth in Cameroon with specific reference to coffee, bananas and cocoa using the co-integration test. The results found mixed effects on economic growth. The export of coffee and the export of bananas have a positive and significant impact on economic growth. On the other hand, the export of cocoa has a negative and not significant impact. The study suggested implementing policies to increase production, and in turn, export, to support economic growth in Cameroon.

Tigist (2015) conducted a study on the impact of agricultural exports on economic growth in Ethiopia. The export products highlighted are coffee and oilseeds. He used the co-integration model, the error correction model and the causal model in the sense of Granger. The results show that the export of coffee and oilseeds has a positive and significant effect on economic growth. There is also a two-way relationship between the export of coffee and economic growth. However, the relationship between the export of oilseeds and economic growth is one-way. It concludes that policies aimed at increasing the productivity and quality of these cash crops are implemented.

Cynthia and Johannes (2017) analyzed the relationship between agricultural exports and economic growth in Namibia. The study used quarterly time series data covering the period between 1990 and 2014. The stationarity, long term and dynamics between gross domestic product (GDP) and agricultural exports to Namibia were estimated using the Dickey Fuller's test (1981), co-integration test and error correction techniques respectively. The results show that agricultural exports have a positive and insignificant effect on economic growth, while non-agricultural exports have a positive and significant effect on GDP. The study also found that agricultural exports, nonagricultural exports, gross domestic fixed capital formation and the consumer price index are long-term determinants of economic growth in Namibia.

In view of this review of the theoretical and empirical literature, it is important to recognize that the crucial role of agriculture in the process of economic growth should not be underlooked. Exports of products such as cocoa, coffee and cotton allowed Cameroon to have good economic growth until the economic crisis that began in the 1980s.

\section{Methodology}

\section{III.1 Data}

The study uses secondary data covering the period 1968-2015. The data come from the database of the World Bank (CD-ROM, 2016) and the National Institute of Statistics of Cameroon (the national accounts of Cameroon 2014). This period is chosen because, the agricultural policy has undergone several reforms (Five-year plans, devaluation, etc.). In addition, this period is characterized by the following phases: expansion phase (1968 to 1985), recession phase (1985 to 1995) and the expansion or economic growth phase from 1995. 


\section{III.2 Specification of the model}

To achieve our objective, we were inspired by the model used by Muhammad Zahir (2012) who examined the contribution of agricultural exports to Pakistan. He established an econometric model based on the production function of the Cobb-Douglas type, ieYt $=\mathrm{A} \mathrm{K} \mathrm{K}^{\mathrm{a}} \mathrm{L}^{\mathrm{b}}$ with $\mathrm{Y}$ being production, $\mathrm{K}$ the factor capital and $\mathrm{L}$ the factor labour, A the residual factor, $\mathrm{a}$ and $\mathrm{b}$ the respective elasticities of capital and labor factors in relation to production and $t$, the period. The introduction of the Logarithm into this production function allows us to have a linear Log-Log model which allows us to make analysis in terms of elasticity. And it is from this model that we determine in an original way our multiple regression equation for the estimation, that is:

$$
\begin{gathered}
\operatorname{LogCRO}_{t}=\log \beta_{0}+\beta_{1} \operatorname{LogCAC}_{t}+\beta_{2} \log C A F_{t}+\beta_{3} \operatorname{LogCOT}_{t}+\beta_{4} \operatorname{LogTCH}_{t}+\beta_{5} \operatorname{LogINF}_{t} \\
+\beta_{6} \operatorname{LogPRO}_{t}+\beta_{7} \log \operatorname{LRO}_{t-1}+\varepsilon_{t}
\end{gathered}
$$

With

$\operatorname{LogCRO}_{\mathrm{t}}$ :Logarithm of real GDP that measures economic growth in period $t$,

$\operatorname{LogCRO}_{\mathrm{t}-1}$ : Logarithm of real GDP delayed by a period considered as an instrumental variable,

$\operatorname{LogCAC} C_{t}:$ Logarithm of cocoa export value in tonnes,

$\operatorname{LogCAF}:$ Logarithm of the value of coffee exports in tonnes,

$\operatorname{LogCOT}_{t}:$ Logarithm of the value of cotton exports in tonnes,

$\log \mathrm{TCH}_{t}:$ Exchange rate logarithm,

$\operatorname{LogINF}_{t}:$ Logarithm of inflation as measured by the consumer price index,

$\operatorname{LogPRO}_{\mathrm{t}}$ :Log value of cocoa, coffee and cotton exports, which measures export stability.

$\mathrm{t}$ : Study period from 1968 to 2015 ,

$\varepsilon_{\mathrm{t}}$ : Stochastic error term

\section{III.3. Estimation techniques}

The preliminary test is that of unit root. There are a multitude of methods for testing whether a series has a unit root or not. In this study, and from the E-views software, we highlighted the Augmented Dikey Fuller test (Granger, 1988) to detect the presence of the unit root. The use of this test is due to the fact that the data in longitudinal section maintain a constant distribution over time. It avoids the case of fallacious regressions.

Following this test applied to each variable, the generalized moments method was applied to the regression model. The choice is made because of its consistent, efficient and normally asymptotic character in the class of all estimators which do not use extra information apart from that of the conditions of the moment. Developed by Hansen (1982), it allows to master auto correlation and heteroscedasticity. One of the peculiarities of this method is the evidence of instrumental variables made up of exogenous and endogenous variables delayed by one or two periods, to neutralize the problems mentioned above (Timmer, 2002).

\section{RESULTS}

Table 1 presents the stationarity test results of all the estimation variables taken individually.

Table 1: Results of the unit root test

\begin{tabular}{|c|c|c|c|c|}
\hline \hline Variables & Test & Probability & Décision. & Intégration order \\
\hline CRO & ADF & $0,0076^{*}$ & Stationary & $\mathrm{I}(1)$ \\
\hline CAF & ADF & $0,0060^{*}$ & Stationary & $\mathrm{I}(0), \mathrm{I}(1)$ \\
\hline $\mathrm{COT}$ & ADF & 0,6919 & Non stationary & - \\
\hline $\mathrm{TCH}$ & ADF & $0,0035^{*}$ & Stationary & $\mathrm{I}(1)$ \\
\hline \hline
\end{tabular}


IRA-International Journal of Management \& Social Sciences

\begin{tabular}{|c|c|c|c|c|}
\hline CAC & ADF & 0,3303 & Non stationary & - \\
\hline TINF & ADF & $0,0004^{*}$ & Stationary & $\mathrm{I}(0), \mathrm{I}(1)$ \\
\hline
\end{tabular}

Source: Authors Note: stationary variables at $1 \%=*$

It appears from this table that two variables are non-stationary, namely the export of cocoa and cotton because the probability is greater than the different significance thresholds. Variables such as economic growth, the exchange rate, coffee exports and the inflation rate are stationary. It is therefore important to recognize that, the endogenous variable is stationary and other non-stationary exogenous variables. From the group stationarity property, we proceeded to the direct estimation of the model by the Generalized Moment Method (MMG).

Table 2 presents the results of the estimates of the impact of cocoa, coffee and cotton exports on economic growth in Cameroon by the MMG.

Table 2: Result of the MMG estimate

\begin{tabular}{|c|c|c|c|c|}
\hline Variables & Coefficient & Std. Error & t-Statistic & Prob. \\
\hline $\mathrm{C}$ & $1,356^{* *}$ & 0,497 & 2,726 & 0,010 \\
\hline CAC & $-0,193 *$ & 0,108 & $-1,780$ & 0,085 \\
\hline CAF & $-0,019$ & 0,052 & $-0,374$ & 0,710 \\
\hline COT & 0,016 & 0,017 & 0,940 & 0,354 \\
\hline $\mathrm{TCH}$ & $-0,235 * * *$ & 0,063 & $-3,696$ & 0,000 \\
\hline PRO & $0,083 * * *$ & 0,015 & 5,342 & 0,000 \\
\hline $\mathrm{CRO}(-1)$ & $\mathbf{0 , 8 3 1} * * *$ & 0,103 & 8,042 & 0,000 \\
\hline $\mathrm{CRO}(-2)$ & 0,183 & 0,116 & 1,569 & 0,127 \\
\hline TINF & $0,004 * * *$ & 0,001 & 3,721 & 0,000 \\
\hline $\operatorname{COT}(-1)$ & $-0,010$ & 0,021 & $-0,478$ & 0,635 \\
\hline CAF(-1) & $-0,040$ & 0,068 & $-0,588$ & 0,560 \\
\hline $\mathrm{CAC}(-1)$ & $-0,123$ & 0,102 & $-1,209$ & 0,235 \\
\hline $\mathrm{TCH}(-1)$ & $0,292 * * *$ & 0,072 & 4,040 & 0,000 \\
\hline \multicolumn{5}{|c|}{$\mathrm{R}^{2}=0,951$} \\
\hline
\end{tabular}

Source; Authors Note: Significance to $1 \%=* * *, 5 \%=* *$ et $10 \%=*$

This table shows that the independent variables explain $95.1 \%$ of economic growth, and at the same time that there is no autocorrelation because the value of Durbin Watson is equal to 2.368. Economic growth delayed by one period and exchange rate delayed by one period are considered to be effective analytical tools since these two variables are significant at $1 \%$. The results show that three variables are significant (cocoa export, exchange rate and inflation rate) and two are not significant (coffee and cotton exports).

\section{Discussions}

The export of cocoa has a negative and significant effect on economic growth. This situation is well explained in the case of Cameroon by the fact that this product has experienced many fluctuations from the 1980s to the present day. Thus, we can note the decline in production and productivity, the poor quality of the product and the fall in price on the international market (source of abandonment of plantations by most national cooperatives). This result is 
contrary to that of Shashi and Marcella's (2010) study in Ghana, which showed a positive contribution of cocoa exports to growth.

The export of cotton has a positive and significant influence on economic growth. However, we note a negative correlation with coffee. When cotton exports increase by $1 \%$, economic growth increases by $1.6 \%$. The $1 \%$ increase in coffee exports lead to a $1.9 \%$ drop in economic growth. It is therefore important to note that the low contribution of coffee exports to economic growth in Cameroon is explained by fluctuations in international prices of raw materials, the black market developed by the planters of the management structure, the absence of the planters' subsidy. Our results contradict those of Tigist (2015) who concluded that there is a positive and significant contribution of coffee to growth in Ethiopia. The results are contrary to those found by Noula et al. (2014). This contradiction can be explained by the difference in the methodologies used.

The exchange rate negatively and significantly influences economic growth. The CFA franc having parity with the euro tends to depreciate, which makes Cameroonian products more competitive on the international scene. So, one would think that the increase in growth from 1995 is partly due to the recovery of the competitiveness of agricultural products on the world market.

The inflation rate is significant with a positive correlation. This stimulates the planters because one of the causes of the fall in agricultural exports is due to the fall in the prices of these products in favor of petroleum products and this has contributed to the abandonment of plantations and the closure of many cooperatives in this area. Thus, a $1 \%$ increase in inflation leads to a $0.4 \%$ increase in economic growth.

There is a positive correlation between the proxy variable which represents the stability of agricultural exports and economic growth. When the stability of agricultural exports varies by $1 \%$, economic growth varies by $8.3 \%$ in the same direction, all other things being equal. If we stick to the length of the different periods to explain the positive and significant impact, we note the period of agricultural stability which goes from 1960 to 1985 with the effectiveness of the five-year plans and from 1995 to 2013 with a large number of agricultural policy reforms such as agricultural cooperatives.

\section{Conclusion}

The objective of this work was to study the impact of agricultural exports on economic growth in Cameroon over a period from 1968 to 2013. A significant period is marked by two economic systems namely planning and liberalization. The results obtained through the MMG estimate show that cocoa and cotton exports positively influence economic growth. On the other hand, that of coffee has a negative influence. One of the most striking conclusions is that which shows that, despite the significant nature of cocoa exports, its sign is contrary to what would be expected (negative sign instead of a positive sign). The export of coffee being insignificant with a negative sign invalidates the hypothesis of a positive contribution.

In view of the results obtained, farmers should be encouraged to form cooperatives to be open to loan systems which will help to increase productivity. In addition, research activities on improving the quality of agricultural products sold abroad should be funded by the government (search for competitiveness). It is suggested that the government of Cameroon should make structural changes to agricultural exports by converting its agricultural exports into high value-added products. In addition, the diversification of exports sought by Cameroon requires the creation of agroindustrial industries.

\section{References}

[1]. ADELMAN, I. (1984). Beyond export-led growth. World Development, 129, 137-149.

[2]. BALASSA, B. (1978). Exports and growth: further evidence. Journal of development economics, 5, 181-189.

[3]. CHOW, P.C.Y. (1987). Causality between export growth and industrial development. Journal of Development Economics, 26, 55-63.

[4]. CYNTHIA, S. et JOHANNES, P.S. (2017). Agricultural exports and economic growth in Namibia. European Journal of Basic and Applied Sciences, 4, 1, 1-10.

[5]. DARRAT. A. (1987). Are exports an engine of growth? Another look at the evidence. Applied economics, 19, $277-283$.

[6]. DAWSON.P.J. (2005). Agricultural export and economic growth in less developed countries. Agricultural economics, $33,145-152$. 
[7]. De JANVRY, A. (1984). Searching for styles of development: lessons from Latin America and implications for India. Working paper, $\mathrm{n}^{\circ}$ 357. Berkeley, California, USA, University of California, Department of Agricultural and Resources Economics.

[8]. DICKEY, D. et FULLER W. (1981). Likelihood ratio statistics for autoregressive time series with a unit root. Econometrica, 49, 1057-1072.

[9]. EKIRAN, J., AWE, I., OGUNJOBI, J. (2014). Agricultural export and economic growth in Nigeria: A multivariate Johansen cointegration analysis. International Journal of Arts and Commerce, 3, 3, 1-10.

[10].FEDER, G. (1983). On export and economic growth. Journal of Development Economics, 12, 59-73.

[11].GRANGER, W.J. (1988). Some recent developments in a concept of causality. Journal of Econometrica, 39, $199-211$.

[12].HANSEN (1982). Large sample properties of GMM estimator. Economica, 50, 1029-1054.

[13].HELLER, P.S. et PORTER, R.C. (1978). Exports and growth: an empirical reinvestigation. Journal of Development Economics, 5, 191-193.

[14].HIRSCHMAN, A.O. (1958). The Strategy of Economic Development. New Haven, Yale University.

[15].JUNG, W.S. AND MARSHALL, P.J. (1985). Exports, growth and causality in developing countries. Journal of Development Economics, 18, 1-12.

[16].KALECKI, M. (1971). Selected Essays on the Dynamics of the Capitalist Economy 1933-1970. London: Cambridge University Press.

[17].KORMENDI, R.C. ${ }^{2}$ et MEQUIRE, P.G. (1985). Macroeconomic determinants of growth: cross-country evidence. Journal of Monetary Economics, 16, 2, 141-163.

[18].KUZNETS, .S. (1968). Toward a Theory of Economic Growth with Reflections on the Economic growth of nations. New York: Norton.

[19].LEWIS, W.A. (1954). Economic development with unlimited supplies of labor. Manchester School of Economics, 20, 139-91.

[20].MELLOR, J. (1976). The new economics of growth: a strategy for India and the developing world. Ithaca, New York, Cornell University Press.

[21].MINADER (2015). Diagnostic du sous-secteur agricole. Document de travail.

[22].MINADER (2010). Evolution de la production agricole au Cameroun. Document de travail.

[23]. MUHAMMAD ZAHIR (2012). Contribution of agricultural export in Economic growth in Pakistan. Journal of Commercial and Sociology. Science, 6, 1, 1-14.

[24].NOULA, A. G., SAMA, G. L. et GWAH, M.D. (2013). Impact of agricultural export on economic growth of Cameroon: Case of Coffee, Banana and Cocoa. International journal of business and management review, 1 1, 1-28.

[25]. OLUWASEUN G, ADEYEMI O., EVANS, O. (2013). Agricultural Exports and Economic Growth in Nigeria .Journal of Economics and Sustainable Development, 4, 16, 2-18.

[26].RAM, R. (1987). Exports and economic growth in developing countries: evidence from time-series and cross-section data. Economic Development and Cultural Change, 36, 5172.

[27].ROSENSTEIN-RODAN, P.N. (1943). Problems of industrialization of Eastern and South-Eastern Europe. Economic Journal, 53, 202-11.

[28].ROSTOW (1963). Les étapes de la croissance économique. Éditions du Seuil, 252 pages.

[29].SHARMA, S. et DHARMENDRA, D. (1994). Causal analyses between exports and economic growth in developing countries. Applied Economic, 26:1145 - 57.

[30].SHASHI, K. et MARCELLA, V. (2000). Coco in Ghana shaping the success of an economy. International journal of business and management review, 1, 1-10.

[31].TIGIST, Y. (2015). Impact of agricultural exports on economic growth in Ethiopia: the case of coffee, oilseed and pulses. Egerton University thesis, 1-82.

[32].TIMMER (2002). Agriculture and Economic Development. in Gardner and G. Rausser eds., Handbook of Agricultural Economics, Vol 2: Elsevier Science B.V.

[33].UKPOLO, V. (1994). Export composition and growth of selected low-income African countries: evidence from timeseries data. Applied Economics, 26, 5, 445-49.

[34].VOGEL (1994). Structural changes in agriculture: production linkages and agricultural demand-led industrialization. Oxford Economic Papers.

[35].VOIVODAS, C.S. (1973). Exports, foreign capital inflows and economic growth. Journal of International Economics, 22, 337-349. 